\title{
MANAGER COMPETENCIES IN THE AREA OF HUMAN RESOURCES RISK MANAGEMENT*
}

\author{
Edyta Bombiak**
}

\begin{abstract}
Background. Managing organisations in turbulent environments requires high quality competencies. In the knowledge economy, of all managerial skills, the role of human resources risk management skills is clearly growing. The reason is that each stage of human resource management pursued by managers may serve as a potential source of risk related to the need to take personnel-related decisions. Human resources risk is an inherent part of company operations, whereas the social sub-system is an indispensable, key factor for the smooth running of business entities. Therefore, HR risk should be managed, as any other risk type.
\end{abstract}

Research aims. The objective of this research was to carry out a diagnosis of manager competencies in the area of human resources risk management.

Methodology. The article was based on the analysis of literature and a diagnostic survey using a questionnaire survey.

Key findings. On the basis of the research conducted with the application of a diagnostic survey, it was concluded that although managers had a significant potential for the management of this specific risk type, it was not used to a full extent in all of the analysed organisations. Furthermore, the analysis showed that a barrier limiting effective human resources risk management oriented at generating an added value was created by negative attitudes, such as perceiving human resources risk mainly as a threat and striving to avoid it.

Keywords: competencies, human resources risk, human resources risk management.

* The research was carried out under the research theme No. 500/18/S financed from by a science grant provided by the Ministry of Science and Higher Education of Poland.

** Faculty of Economic and Legal Sciences, Siedlce University of Natural Sciences and Humanities, ul. Konarskiego 2, 08-110 Siedlce. E-mail: edyta.bombiak@uph.edu.pl 


\section{INTRODUCTION}

Managing a present-day organisation in an unsettled environment involves a well-trained managerial staff. Therefore, so much attention is being paid nowadays to the development of managerial competencies. Currently, competent managers become a strategic resource, which oftentimes determines whether the business lives or dies. That is why requirements relating to modern managers are increasing. The quantitative and qualitative scopes of their competencies are key to effective use of tangible and non-tangible company assets. Dynamic changes surrounding today's organisations and, in particular, more turmoil and disturbance, are constantly raising not only corporate management standards, but also expectations towards manager competencies. Top quality managerial competencies promote company development and prompt adaptation to the surrounding volatile conditions.

The flux in the area of management contributes to a constant evolution of the scope of functions managers fulfil and the skills they should master. To play the role of a manager necessitates a combination of skills, experience and talents. The order of managerial skills is also subject to continuous fluctuations. Competencies treated as strategic today, tomorrow may become operational. All this leads to the evolution of the present-day manager competence model and requires new competence acquisition, which would help one cope with turbulent environments.

Without doubt one of such competencies is the ability to manage human resources risk. The need to improve it results from the fact that the contemporary world stimulates rapid and difficult to predict changes, also in the field of human resource management. Every stage of human resource management is a potential source of risk related to the need to take personnel-related decisions. This makes an effective performance of the human resource function unattainable without an analysis and evaluation of the factors of human resources-related risk and its proper management. In this context the issue of manager competencies in the area of human resource risk management becomes of primordial importance. While analysing source literature, one may note a shortage of both theoretical studies and empirical research in the field and, hence, the intention of the author was to fill in the gap, at least to some extent. 
The aim of this research was to identify manager competencies in the area of human resources risk management, with reference to the following components: knowledge, skills, and attitudes. To attain this goal, a review of source literature and an analysis of the results of own studies based on a diagnostic survey, with the use of a questionnaire survey, were employed. In the course of research, attempts were made to verify the following theses:

1. Managers have knowledge regarding human resources risk management; however, it is not fully used in practice.

2. The dominant attitude presented by managers with regards to human resources risk is negative, as reflected by regarding the risk to be a threat and striving to avoid it.

Throughout the study, it was assumed that improving human resources risk management skills may indeed be the foundation of the shaping of a new idea of management, focusing on using the described risk as a key enterprise development factor.

\section{EMPLOYEE COMPETENCIES IN DEFINITIONS}

The idea of competence is of interest to many research fields and, as such, it has been interpreted in a number of ways. The interdisciplinary nature of the term leads to difficulties with its clear formulation. In the science of management, competencies may refer to (Zbiegien-Maciag, 2006, p. 170):

- characteristic features of a position - as such, they reflect the scope of rights to take decisions or to perform specific tasks (Ratajczak, 2007, p. 83);

- characteristic features of man - as such, they denote the ability to convert a given potential into factual behaviors and actions (Sobocińska, 2016, p. 88).

Competencies are personal resources of each individual, which allow one to carry out his or her professional tasks at an adequate level. They are the features constituting foundations of effective performance and working behaviour. They are formed as a result of integration of various elements of employee potential. It is said that competencies are indicators which best allow one to assess people's capacities and abilities to accomplish specific goals, whereas having particular competencies means that a given person has the required 
skills and knowledge and is authorised to pursue a given action and to take decisions in a relevant field (Fraś, 2011, p. 359). One element which distinguishes competencies is the ability aspect.

Table 1 outlines a selection of definitions of competencies, accounting for their narrow and broad approaches. In the narrow sense, competencies are most frequently viewed as the totality of knowledge, skills, and attitudes. Whereas, in the broader perspective, in addition to the above mentioned elements, they include aptitudes and interests, talents, education, experience, inner motivation, attitudes, and behaviours, styles of action, health condition, physical and mental fitness, formal right to act on behalf of a given organisation, commitment to values, and ethical principles (Oleksyn, 2006, p. 39; Rakowska, 2000, p. 27; Sajkiewicz, 2002, pp. 60-61); although, no consensus has been reached with regards thereto.

Table 1. Narrow and broad approaches to competencies

\begin{tabular}{|l|l|}
\hline \multicolumn{1}{|c|}{ Author } & \multicolumn{1}{c|}{ Definition } \\
\hline The narrow approach to competencies \\
\hline H. Król (2006) & $\begin{array}{l}\text { Competencies are aptitudes regarding knowledge, skills and atti- } \\
\text { tudes, required to complete professional tasks at an effective and (or) } \\
\text { distinguishable level, relevant to the standards set by an organisa- } \\
\text { tion for a given position. }\end{array}$ \\
\hline $\begin{array}{l}\text { G. Filipowicz } \\
\text { (2004) }\end{array}$ & $\begin{array}{l}\text { Competencies are talents in the area of knowledge, skills, and atti- } \\
\text { tudes, which allow one to accomplish professional tasks at a suitable } \\
\text { level. }\end{array}$ \\
\hline $\begin{array}{l}\text { E. Michalski } \\
\text { 2011) }\end{array}$ & $\begin{array}{l}\text { Competencies involve having knowledge and experience, which allow } \\
\text { one to carry out his or her obligations correctly and take the right } \\
\text { decisions. }\end{array}$ \\
\hline $\begin{array}{l}\text { F. Draganidis, } \\
\text { G. Mentzas } \\
\text { (2006) }\end{array}$ & $\begin{array}{l}\text { Competencies are a combination of tacit and explicit knowledge, } \\
\text { behaviour and skills, that gives someone the potential for effective- } \\
\text { ness in task performance. }\end{array}$ \\
\hline The broad approach to competencies \\
\hline Marrelli (1998) & $\begin{array}{l}\text { Competencies are measurable human capabilities that are required } \\
\text { for effective work performance demands. }\end{array}$ \\
\hline $\begin{array}{l}\text { Dubois (1998) } \\
\text { R. Boyatzis }\end{array}$ & $\begin{array}{l}\text { Competencies are those characteristics - knowledge, skills, mindsets, } \\
\text { thought patterns, and the like that, when used either singularly or in } \\
\text { various combinations, result in successful performance. }\end{array}$ \\
\hline $\begin{array}{l}\text { Competencies are a set of traits of a given person, which consists of } \\
\text { elements typical of a person, such as motivation, personal features, } \\
\text { skills, and self-assessment related to one's functioning as a group } \\
\text { member, and knowledge the person has acquired or uses. }\end{array}$ \\
Schema & $\begin{array}{l}\text { A specific, identifiable, definable, and measurable knowledge, skill, } \\
\text { ability and/or other deployment-related characteristic (e.g. attitude, } \\
\text { behaviour, physical ability) which a human resource may possess } \\
\text { and which is necessary for, or material to, the performance of an } \\
\text { activity within a specific business context. }\end{array}$ \\
\hline
\end{tabular}


Table 1. cd.

\begin{tabular}{|l|l|}
\hline \multicolumn{1}{|c|}{ Author } & \multicolumn{1}{c|}{ Definition } \\
\hline $\begin{array}{l}\text { G.O. Klemp } \\
\text { (1980) }\end{array}$ & $\begin{array}{l}\text { Competencies are a set of individual features allowing one an effec- } \\
\text { tive and (or) outstanding job-related task performance. }\end{array}$ \\
\hline $\begin{array}{l}\text { M. Montmollin } \\
\text { (1984) }\end{array}$ & $\begin{array}{l}\text { Competencies are established sets of knowledge and skills, typical } \\
\text { behavioural patterns, standard procedures, modes of understanding, } \\
\text { which may be applied without learning anew. }\end{array}$ \\
\hline $\begin{array}{l}\text { C. Levy-Leboyer } \\
\text { (1996) }\end{array}$ & $\begin{array}{l}\text { Competencies are a set of behaviours which certain individuals mas- } \\
\text { ter better than others, which consequently leads to them operating } \\
\text { more effectively and efficiently in certain situations. Competencies } \\
\text { refer to an integrated use of one's capabilities, personality traits, } \\
\text { and acquired knowledge and skills with the intention to successfully } \\
\text { complete a complex mission as part of the enterprise. }\end{array}$ \\
\hline $\begin{array}{l}\text { T. Rostowski } \\
\text { (2004) }\end{array}$ & $\begin{array}{l}\text { All employee features which, when challenged and developed in the } \\
\text { process of work, lead to the achievements of results in corresponding } \\
\text { to strategic company goals. }\end{array}$ \\
\hline $\begin{array}{l}\text { M. Armstrong } \\
\text { (2000) }\end{array}$ & $\begin{array}{l}\text { Competencies constitute a potential contributing to the attainment } \\
\text { of specific, measurable results. }\end{array}$ \\
\hline $\begin{array}{l}\text { Pocztowski } \\
\text { (2003) }\end{array}$ & $\begin{array}{l}\text { Competencies entail the total of relatively durable human features } \\
\text { forming a causal link with high or outstanding effects of one's work, } \\
\text { having a dimension of universality. }\end{array}$ \\
\hline $\begin{array}{l}\text { S. Whiddett, } \\
\text { S. Hollyforde } \\
\text { (2003) }\end{array}$ & $\begin{array}{l}\text { A competency regarding the work performed is a set of traits of } \\
\text { a given person, which consists of elements typical of a person, such } \\
\text { as motivation, personal features, skills, self-assessment related to } \\
\text { one's functioning as a group member, and knowledge the person has } \\
\text { acquired or uses. }\end{array}$ \\
\hline
\end{tabular}

Source: Rostowski, 2004, p. 40; Król, 2006, p. 82; Oleksyn, 2006, p. 86, Filipowicz, 2004, p. 17; Klemp, 1980; Armstrong, 2000, p. 241; Levy-Leboyer, 1997, p. 32; Boyatzis, 2008, p. 8; Michalski, 2011, pp. 125-136; Draganidis, Mentzas, 2006, pp. 51-64; Dubois, 1998; Amherst, Marrelli, 1998, pp. 8-17; Pocztowski, 2003, p. 153; Whiddett, Hollyforde, 2003, p. 13.

The main matter of dispute regarding the nature of competency is the clarification of the relationship between competencies and personality features. Analysis of the definitions shows that in the narrow approach, competencies seem to be independent of the mental aptitude of an individual; whereas, from the broad perspective, personality traits are their integral component. The author hereof reckons that personal capacities determine the speed and ease of learning. Hence, their exclusion from the set of elements making up competencies cannot be justified.

Competencies are the most salient components of the human capital. They feature specific characteristics, which make them valuable company resources (Walkowiak, 2007, p. 23; Zbiegień-Maciag, 2006, pp. 171-174; Sadler, 1997, p. 197), above all: 
- they are rare and unique - there are no two people with an identical competency potential;

- they are complex - each competency is composed of a number of elements (knowledge, skills, attitudes, etc.);

- they are dynamic - they can be developed by the acquisition of new experiences;

- combining them produces a synergy effect;

- they are intangible and cannot be measured except for the action in which they come to light;

- they are relative - they have a value and meaning in a given professional context;

- they are transformable - they may be developed or adapted so that they are useful at different job positions;

- they are inseparably related to their owner;

- they disclose actions.

All in all, it can be said that competencies are personal resources of each employee. They are equivalents of the intellectual capital of a person. As major components of the human capital, competencies play an important role in the creation of the most valuable and profitable capital of contemporary organisations, i.e. the intellectual capital. Without doubt, competencies of managerial staff play a salient role in gaining a competitive advantage.

\section{HUMAN RESOURCES RISK MANAGEMENT AS A KEY MANAGERIAL COMPETENCY}

A manager is a person who carries out the process of management by fulfilling managerial functions, such as planning, organising, motivating, and controlling. The work of a manager involves decision-making, effective administration of company resources, managing human teams, continuous company enhancement, and adaptation to changes occurring in unsettled environments. It is characterised by a high level of complexity of activities, their changeable course, and programming difficulties (Lachiewicz, 1994, p. 8). For managerial tasks to be performed effectively, they require numerous competencies.

The idea of managerial competencies is used to denote a set of characteristics, knowledge and skills, which - in a given situation - allow one expeditious employee management, effective use of employee potential, 
and adequate administration of physical, financial, and information resources to attain organisations' objectives (Witaszek, 2011, p. 313). Managerial competencies entail skills related to professional and social activities (Zukowski, 2008, p. 29). It is highlighted in literature that an effective manager should have both soft and hard competencies. Soft competencies are seen as congruent with mental and physical features and skills and emotional intelligence. They determine a manager's behaviours and his or her attitude to interpersonal relations (Fastnacht, 2006, pp. 109-114). Hard competencies, in turn, consist in specialist knowledge, skills and qualifications. The level of these competencies will be key to management effectiveness.

In order to succeed on the market, an organisation needs a required set (portfolio) of competencies. Needless to say, competency requirements change with developments of the enterprise and the conditions in which it operates. Thus, it is hard to provide a closed and exhaustive list of managerial competencies and literature abounds in a variety of profiles (Mikuła, 2001, pp. 167-176; Rakowska \& Sitko-Lutek, 2003, pp. 34-36; Lichtarski, 2008, pp. 56-60; Whetten et al., 1996; Penc, 2005, pp. 236-237; Żukowski, 2008, pp. 25-40). However, there is a consensus with regards to the fact that the manager's competency portfolio should include the following (Katz, 1974, pp. 90-102; Walkowiak, 2004, p. 27; Stoner \& Wankel, 1994, p. 36):

- technical competencies, i.e. specialist knowledge about working methods, processes, and tools, and the ability to apply it in practice;

- conceptual competencies, which are defined as mental skills allowing one to coordinate and integrate actions in accordance with company goals (analysing, interpreting, and solving problems);

- $\quad$ social competencies, which are related to the ability to handle people, i.e. to communicate, motivate, lead, create a positive atmosphere or solve conflicts.

Social competencies are equally important at all managerial positions, for the job of a manager will always involve working with people and via people. These competencies let one have a direct influence on his or her subordinates. The meaning of the remaining competencies depends on the level of management. In the case of junior managers, the most prominent are technical competencies; whereas, as managers progress and climb their career ladders, we can note that conceptual 
competencies become more valuable. The author reckons that the competence the role of which is increasing in the knowledge economy is the ability to manage human resources risk.

Human resources risk is associated with the administration of the most crucial capital in knowledge economy, i.e. the human capital. It is classified as an operational risk (Jajuga, 2009, p. 270) and defined as:

- possibility of incurring a loss (financial, reputational, relational) due to human imperfection (errors resulting from insufficient knowledge, skills, suitability, an employee knowingly violating company policies or laws) and imperfection of HR management processes (Bochniarz \& Gugała, 2005, p. 98),

- a potential hazard which threatens company objectives and which stems from negligence and/or improper use of human capital (Kropp, 2004, pp. 131-132),

- a deviation from company objectives due to human resources involvement in operational activities arising from unpredictable employee behaviours and the adoption of improper decisions with regards to human factor management or the application of imperfect procedures (Zhao \& Jia, 2006, pp. 830-831).

From a mathematical perspective, it is defined as the product of the probability of a certain event consequential to a human resource decision, and the consequences of that event (Czerska \& Rutka, 2016, p. 23). The risk so defined allows both positive and negative deviations from the set goal, which makes it a part of the contemporary approach to organisational risk management. This approach rejects the stereotypical association of risk with threats only and accounts for chances or opportunities to gain additional benefits and a competitive edge thanks to skilful risk management.

The source of risk related to the human factor may be both external conditions, independent of enterprises (e.g. demographic trends, changes in law), and internal procedures, processes and systems (such as employee selection procedures, evaluation, motivation and remuneration systems, training policies). In order to manage the risk adequately, it needs to be correctly recognised, its value needs to be measured, the probability of risk must be evaluated, the methods to deal with risk must be selected, and to this aim a special organisational structure must be developed. This, in turn, requires special competencies.

Therefore, considering the crucial role the human factor plays in the process of organisational success achievement, and unsettled 
environments, human resources risk management may be perceived as the key managerial competency. Turbulent environments feature high changeability, which continually generates novel sources of risk entailing nearly all areas of management and human resource management. Individual employees, as well as each stage of human resource management, may serve as a potential source of risk associated with the need to take personnel decisions. Human resources risk is an inherent part of operations of any entity in which the social sub-system constitutes a key and necessary factor. Source literature holds that risk related to human resources is one of the most important areas of risk (Czerska \& Rutka, 2012, p. 185). This results from the fact that human resources risk occurring at each stage of the personnel process may either enhance or reduce the effectiveness of strategic human resource management (Lipka, 2008, p. 15) via its influence on the consistency of human resource practices at various levels of governance, on the level of human resource function expenses, and the quality and value of the human capital. The challenges of the contemporary knowledge economy make it clear that a disregard for this risk may have serious consequences, such as human capital depreciation. What is more, the achievement of the main objective of strategic human resource management, i.e. the increase in the value of the organisation thanks to possessed human resources, is impossible in the absence of adequate individual sub-process formation, exposed to human resources risk (Bombiak, 2017, pp. 253-269).

Managerial competence development with regards to risk management gives one a chance not only to reduce personnel threats, but also to achieve additional benefits as a consequence of the right administration of human capital or reduction of potential losses related thereto. Accordingly, the personnel decision-making process is streamlined and the establishment of priorities in the area of human resource management is fostered thanks to the resultant comprehensive knowledge about human factor-related threats and opportunities. Ergo, the allocation and use of human capital in a given organisation becomes more effective while the uncertainty of action in the field more limited. Owing to the ability to manage human resources risk, managers can avail of looming opportunities more fluently and achieve greater immunity to the effects of unfavourable personnel events. In view of the above, we can conclude as follows: skilful human resources risk management preconditions effective performance of the personnel 
function in unsettled environments, and as such, constitutes a key managerial competency.

Human resources risk management is, however, a convoluted competency composed of analytic skills, the ability to draw conclusions, predict, and look ahead, required to identify potential risks related to a given personnel process and make decisions regarding its mitigation. Crucial elements of the competency are knowledge regarding human resources risk and its practical implementation, and attitudes towards human resources risk. These components have been analysed in the course of empirical studies.

\section{RESEARCH METHODOLOGY}

The objective of the study was to identify manager competencies in the area of human resources risk management. The study was conducted based on a source literature inquiry and a diagnostic survey method involving a questionnaire survey.

The survey was conducted in 2017 on a population of 180 enterprises with their seat in the Mazovia Province with the application of the CATI technique. The characteristic features of the study population are shown in Table 2.

The target audience of the questionnaire was managerial staff. The study included managers representing all levels of medium-sized and large enterprises located within the Mazovia Province. In the study structure, junior level managers constituted $51 \%$, middle level $-35 \%$, and senior level $-14 \%$. The study managers were employed with entities differing in terms of employment level. The majority of enterprises (81\%) were medium-sized, employing between 50 and 249 people, operating on the market more than 9 years ( $42 \%) .77 \%$ of the managers represented private companies, and $23 \%$ - state-owned enterprises. The variations between the companies included the dominant type of their business activity: production $50 \%$, services $42 \%$, and trade $8 \%$.

In the course of analyses, the following research problems were addressed:

- Do managers have competences regarding human resources risk management?

- Are the competences regarding human resources risk management used in practice? 
- What is the attitude of managers towards human resources risk?

- Is the human resources risk an opportunity or a threat to the functioning of the organisation?

In the course of research, attempts were made to verify the following theses:

1. Managers have knowledge regarding human resources risk management; however, it is not fully used in practice.

2. The dominant attitude presented by managers with regards to human resources risk is negative, as reflected by perceiving the risk as a threat and striving to avoid it.

Table 2. Details of enterprises covered by the research

\begin{tabular}{|l|r|r|}
\hline \multicolumn{1}{|c|}{ Criterion } & Number of Enterprises & Percentage \\
\hline Employment number: & & \\
50-249 employees & 145 & 81 \\
250-499 employees & 11 & 6 \\
500-749 employees & 20 & 2 \\
More than 750 employees & 4 & \\
\hline Time on the market: & & 7 \\
up to 1 year & 13 & 11 \\
1-3 years & 20 & 15 \\
3-5 years & 27 & 14 \\
5-7 years & 25 & 11 \\
7-9 years & 19 & 42 \\
More than 9 years & 76 & 77 \\
\hline Type of ownership: & & 23 \\
private company & 139 & \\
state-owned enterprise & 41 & 41 \\
\hline Scope of operations: & & 29 \\
International & 74 & 13 \\
National & 52 & 17 \\
Regional & 23 & \\
Local & 31 & 42 \\
\hline Main type of activity: & & 51 \\
Services & 76 & 83 \\
Production & 92 & \\
Trade & 14 & \\
\hline Respondent's position: & & \\
senior level & & \\
middle level & & \\
junior level & & \\
\hline & & \\
\hline
\end{tabular}

Source: compiled on the basis of own research. 
The formulation of the former thesis results from the fact that the level of competency depends, above all, on one's knowledge, and next, on the ability to use it correctly. According to the Dictionary of the Polish Language, knowledge is a body of facts acquired by research or learning. It is information regarding a particular domain or a familiarity with something (Słownik..., 2017). It is the product of cognitive, motivational, and social processes' combination. It is produced as a consequence of associations, comparisons, and analyses of various information. It is a mixture of experience, value, contextual information, and expert insight into a given issue, which becomes a framework for the evaluation and legitimisation of new experiences and information (Davenport \& Prusak, 1998, p. 5). This is of primordial importance as an element of professional competencies and, the more intellectual the nature of the work is, the greater its role (Moczydłowska, 2011, pp. 533-544).

\section{MANAGERS' KNOWLEDGE REGARDING HUMAN RESOURCES RISK MANAGEMENT}

Nowadays, knowledge is gaining in importance as an element of personal, organisational and social development. It is placed on an equal footing with land, capital, and work, as the main production factors (Nonaka \& Takeuchi, 2000, p. 23). It was yet another reason why, when examining managerial competencies with regards to human resources risk, the managers were mainly asked about their knowledge in the field and its practical implementation. The answers submitted are shown in Figure 1.

Considering the fact that the subject matter is not extensively covered by source literature, the fact that as many as $83.3 \%$ of the study managers have knowledge concerning human resources risk management is a positive outlook. Now, we should ask ourselves a question: how expert or specialist this knowledge is? To answer the above, we need a more in-depth study in the field. For, in many cases, we may suspect declared knowledge to be superficial.

What is more, there is a clear gap between one's knowledge and its practical application. Only $62.5 \%$ of the managers under study had been using their knowledge in practice. Hence, we can draw a conclusion that there are organisations which do not take advantage of their managers' competencies in the area of human resources risk 


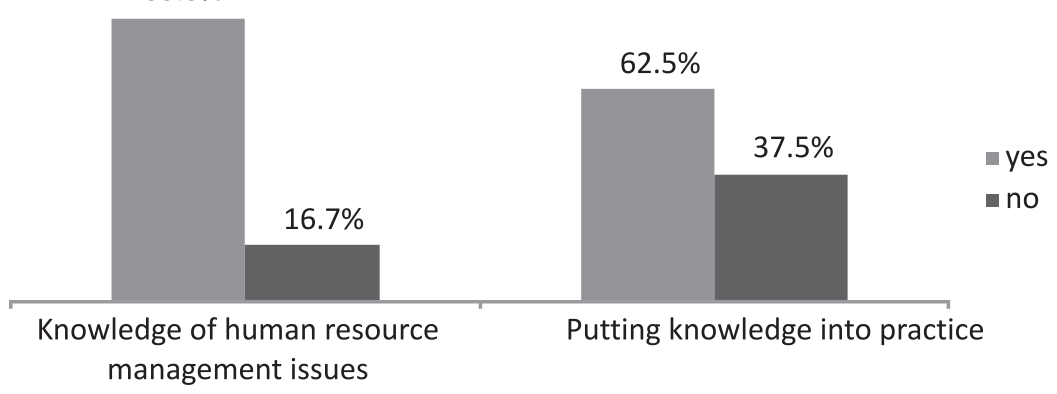

Figure 1. Knowledge of human resources risk and its practical use $(\mathrm{N}=180)$

Source: compiled on the basis of own research.

management. Against this backdrop, we should be questioning ourselves about the reasons behind such a state of affairs. It may result both from the lack of motivation to use it and from the lack of opportunities to do so. The latter might be the case in organisations the strategies of which do not account for human resources risk management policies.

\section{ATTITUDES TO HUMAN RESOURCES RISK ADOPTED BY MANAGERS}

According to the Dictionary of the Polish Language, an attitude is man's look on life or certain phenomena expressing his or her views and behaviours (Słownik..., 2017). J. Turowski defines it as relatively long-lasting tendencies of an individual to behave in a specific manner toward a given item, resulting from his or her opinions, feelings, and aspirations regarding the object of the attitude (Turowski, 2000, p. 59). S. Mika, in turn, explains attitudes as a relatively permanent structure of cognitive and emotional processes and tendencies to specific behaviours relating to a given item or an innate tendency to demonstrate processes through which his or her relation to an item is demonstrated (Mika, 1998, p. 63). One's attitude is, next to knowledge and skills, the most frequently cited element of professional competencies. It plays a crucial role from the point of view of the efficiency of task performance.

Decisions concerning risk-taking are person-specific and are subject to a decision-maker's attitude to risk. We can observe two contradictory attitudes to human resources risk (Król, 2010, p. 53): 
- $\quad$ an active attitude, expressed by making informed decisions to take up risky activities as an opportunity to gain non-standard inspirations and benefits which will allow one to gain a competitive advantage;

- a passive attitude, featuring risk avoidance, preference for familiar, predictable situations and routine activities. The latter leads to risk aversion.

The two approaches depend on numerous factors, such as access to information, freedom of entering into transactions and making decisions, cultural factors (the system of values), and factors related to decision-making entities, such as age, sex, knowledge, and experience (Borkowski, 2008, p. 23).

The analysis of study results presented in Figure 2 demonstrates that the majority of the study managers demonstrated a risk-avoidance stance, i.e. a passive attitude. We should note that this aversion to risk is the most often seen business activity approach. This means that the more risky the decision is, the greater its effect ought to be, for it should contain a bonus for the inherent risk (the higher the level of aversion is, however, the larger the bonus for the decision-maker to take the risk) (Jajuga, 2007, p. 14). Generally, it can be observed that people show aversion to risk, unless they envisage additional benefits related thereto.
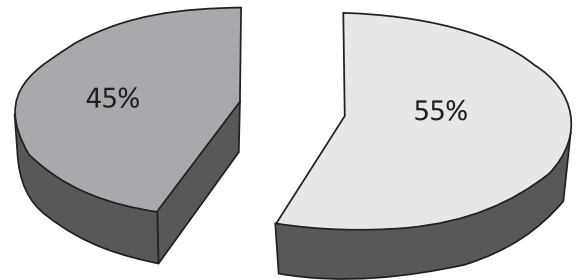

$\square \mathrm{I}$ try to avoid the human resources risk

$\square$ I take the human

resources risk

Figure 2. Attitudes to human resources risk adopted by managers $(\mathrm{N}=180)$

Source: compiled on the basis of own research.

Adopting a passive approach to human resources risk generates risk in itself, as it usually results in:

- the absence of identification of threats in the area of human resource management;

- the absence of evaluation of human resources risk (i.e. the identification of the likelihood of risk and its consequences), 
- the absence of programmes developed for risk prevention,

- the absence of actions protecting against the consequences (material and non-material) of risk,

- the absence of the monitoring and reporting of any undesired personnel events.

At times, passivity leads to ignoring risks and failing to take actions against them. Given that not all of the human resources risk factors may be evaded, the likelihood of generating losses related to the materialisation of risks increases.

On the other hand, in the case of the less frequently presented active behaviour, managerial staff will be more prone to take uncertain personnel decisions. Managers representing the active attitude make informed decisions, assuming a complete or partial responsibility for both their positive and negative consequences.

Passive approaches to human resources risk may stem from the low frequency of risk or a belief that it has no significant influence on company operations. Hence, the managers under study were asked to evaluate the level of human resources risk on a scale of 1 through 5 , where 1 represents a very low risk level, and 5 a very high one. The results of the assessment are shown in Figure 3.

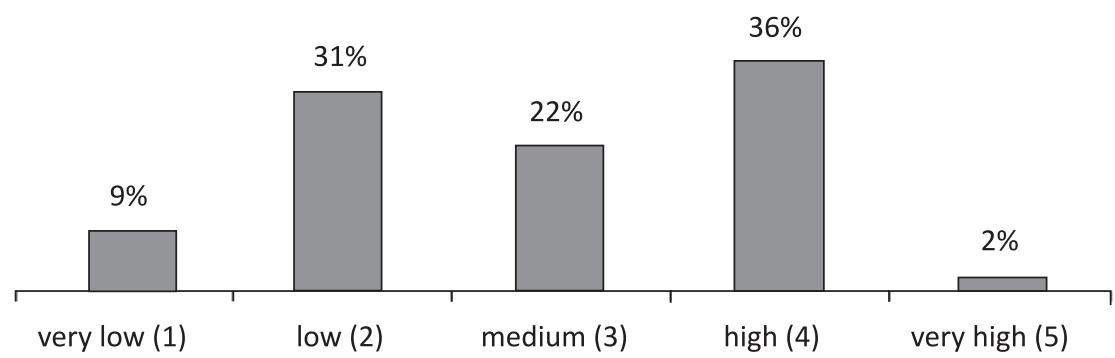

Figure 3. Human resources risk assessment in the organisations under study $(\mathrm{N}=180)$

Source: compiled on the basis of own research.

The analysis demonstrates that the presented opinions vary significantly. Even though 36\% of the polled managers indicated a high level of human resources risk (level 4), an equally large group (31\%) claimed that the level was low (level 2). An average risk level was established at 2.9. Therefore, we may be referring to a moderate-level human resources risk. Such an assessment may, 
to some extent, account for the passive behaviour of the managers under study.

Attitudes to risk may also be derivatives of the way risk is perceived. In the case of the negative risk concept, wherein risk is identified merely with threats, managers will commit to its neutralisation. On the contrary, in the event of preferences for a neutral risk concept, i.e. consisting in both threats and potential opportunities, managerial staff will be more willing to take uncertain personnel decisions. The manner in which risk is perceived by the polled managers is illustrated in Figure 4.

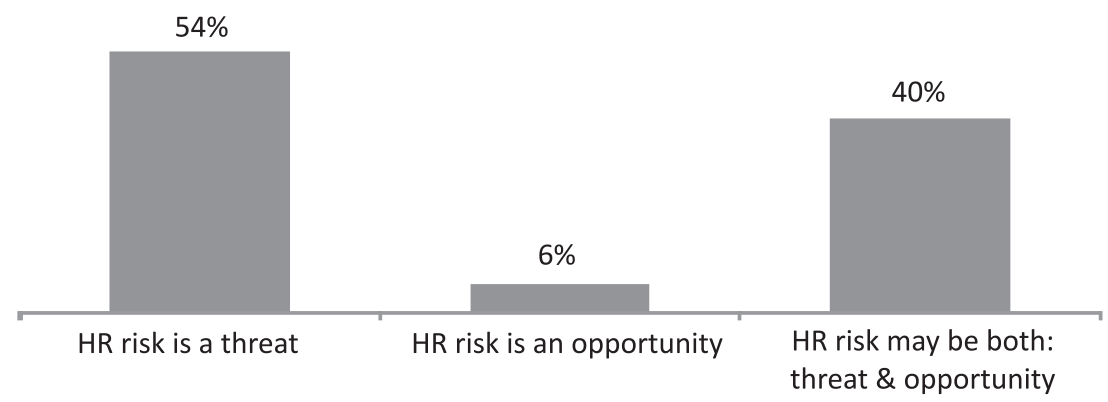

Figure 4. Managers' perception of human resources risk $(\mathrm{N}=180)$

Source: compiled on the basis of own research.

The results indicate that the attitudes toward human resources risk amongst the managers were chiefly negative. More than a half of the polled (54\%) considered this risk as a threat only, which explains why it needs to be avoided (see Figure 4). A vital role in the change of managers' approaches from negative to neutral is played, without a doubt, by human resources risk education and management, as well as by the provision of tools which foster effective process performance.

\section{CONCLUSIONS}

Effective management of human capital in unstable conditions necessitates an enhancement of manager competencies in the area of human resources risk management. Only then could a competitive edge be gained, thanks to personnel-related opportunities and a reduction of human factor-related threats, for human resources risk is an inherent 
part of operations of any entity. As such, it should be managed, just as any other risk type is. The challenges of contemporary knowledge economy make it clear that a disregard for the human resources risk may have serious implications. It is imperative that the risk is managed so as to boost opportunities of achieving an optimum human capital management and, as a consequence, a company success on the market. Therefore, the role of manager competencies in the field is growing.

The research reveals that not all managers have knowledge concerning human resources risk management. We may find it surprising, as everyone should be able to manage such risk in practice because every manager takes personnel decisions and, therefore, deals with such risk type on an everyday basis. It was established that the majority of the managers perceived risk as a threat and attempted to avoid it. Nonetheless, the percentage of the polled who saw the human resources risk as an opportunity to gain benefits was pronounced, too. It seems justified to repeat the study in the future, so that the evolution of managers' attitudes toward this risk type can be diagnosed.

On the basis of the declarations of the managers under study, we can say that there is a large potential with respect to human resources risk management, which remains unexploited in some organisations. In the era of a growing importance of cooperation, from the point of view of the enhancement of human resources risk management processes, it is crucial for the managers to share their expertise with others, as this in itself is a type of a social competency. Such behaviours ought to be reinforced and stimulated with the application of all available incentives. It is particularly important not only due to the need to implement integrated systems of risk management in organisations, but also for the development of continuously learning organisations. An obstacle on the road to human resources risk management competency improvement is a deficit of studies concerning the subject matter. Source literature lacks consistent ideas regarding the methods of risk measurement or risk reporting standards, which is likely to deter practitioners from further field exploration.

The principal limitation of effective human resources risk management is, in the opinion of the author hereof, the conservative approach to risk demonstrated by the managers under study. This leads to equating the risk with threats mainly, which in turn causes risk avoidance. With a view to the above, it appears necessary to shape 
the risk management culture focused on human resources risk as a medium of values indispensable in the process of risk use as a key factor of company development.

\section{REFERENCES}

Amherst, M.A. \& Marrelli, A.F. (1998). An introduction to competency analysis and modeling. Performance Improvement, 37, 8-17.

Armstrong, M. (2000). Zarzadzanie zasobami ludzkimi. Tłum. A. Unterschuetz et al. Kraków: Dom Wydawniczy ABC.

Bochniarz, P. \& Gugała, K. (2005). Budowanie i pomiar kapitału ludzkiego w firmie. Warszawa: Poltext.

Bombiak, E. (2017). Human resources risk as an aspect of human resources management in turbulent environment. In: F. Pinzaru, A. Zbuchea, C. Bratianu, E. Vatamanescu, A. Mitan (eds.). Strategica. Shift. Major Challenges of Today's Economy (pp. 121-146). Bucharest: Tritonic.

Borkowski, P. (2008). Ryzyko w działalności przedsiębiorstw. Gdańsk: Wydawnictwo Uniwersytetu Gdańskiego.

Boyatzis, R. (2008). Competencies in the $21^{\text {st }}$ century. Journal of Management Development, 1, 8-17.

Czerska, M. \& Rutka, R. (2016). Metoda oceny ryzyka personalnego organizacji. Studia Ekonomiczne. Zeszyty Naukowe Uniwersytetu Ekonomicznego w Katowicach, 280, 21-33.

Davenport, T.H. \& Prusak, L. (1998). Working Knowledge: How Organizations Manage What They Know. Boston: Harvard Business School Press.

Draganidis, F. \& Mentzas, G. (2006). Competency based management: A review of systems and approaches. Information Management \& Computer Security, $14,51-64$.

Dubois, D.D. (ed.) (1998). "Preface”, The Competency Casebook: Twelve Studies in Competency-Based Performance Improvement. Amherst: HRD Press.

Fastnacht, D. (2006). Miękkie kompetencje w zarządzaniu. Zeszyty Naukowe Wyższej Szkoły Zarzadzania Ochrona Pracy w Katowicach, 1(2), 109-114.

Filipowicz, G. (2004). Zarzadzanie kompetencjami zawodowymi. Warszawa: PWE. Fraś, J. (2010). Kompetencje menedżera przyszłości. Zeszyty Naukowe Ostrołęckiego Towarzystwa Naukowego, 15, 359-367.

Jajuga, K. (2007). Zarzqdzanie ryzykiem. Warszawa: Wydawnictwo Naukowe PWN. Katz, R.L. (1974). The skills of an effective administrator. Harvard Business Review, 9-10, 90-112. 
Klemp, G.O. (1980). The assessment of occupational competence. In: Report to The National Institute of Education. Washington: National Institute of Education.

Kropp, W. (2004). Entscheidungsorientiertes Personalrisikomanagement. In: R. Bröckermann, W. Pepels (eds.). Personalbindung: Wettbewerbsvorteile durch strategisches Human Resource Management (pp. 131-166). Berlin: Erich Schmidt Verlag GmbH \& Co.

Król, H. (2006). Podstawy koncepcji zarządzania zasobami ludzkimi. In: H. Król, A. Ludwiczyński (eds.). Zarzadzanie zasobami ludzkimi (pp. 50-91). Warszawa: PWN.

Król, M. (2010). Elastyczność zatrudnienia a ryzyko personalne. Wspótczesne Zarzadzanie, 3, 51-61.

Lachiewicz, S. (ed.) (1994). Organizacja pracy kierowniczej. Łódź: Wydawnictwo Absolwent.

Levy-Leboyer, C. (1997). Kierowanie kompetencjami. Bilanse doświadczeń zawodowych. Tłum. M. Egeman. Warszawa: Poltext.

Lichtarski, J.M. (2008). Ewolucja profilu kompetencyjnego kierownika. In: K. Krzakiewicz (ed.). Problemy pracy kierowniczej we wspótczesnym przedsiębiorstwie (pp. 56-63). Poznań: Kreos.

Lipka, A. (2008). Efektywność strategicznego zarządzania zasobami ludzkimi. Human Resources Management, 3-4, 9-23.

Michalski, E. (2011). Paradygmat kompetencji kadry kierowniczej przedsiębiorstwa. Zeszyty Naukowe Wyższej Szkoty Bankowej w Poznaniu, 34, 125-136.

Mika, S. (1998). Psychologia społeczna dla nauczycieli. Warszawa: Żak.

Mikuła, B. (2001). Metody rozwoju kompetencji organizacji. In: C. Sikorski, T. Czapla, M. Malarski (red.). Przeszłość i przyszłość nauk o zarzadzaniu. Metody i techniki zarzqdzania (pp. 167-176). Łódź: Wydawnictwo UŁ.

Moczydłowska, J. (2011). Doskonalenie wiedzy zawodowej jako element zarządzania kompetencjami w sektorze administracji publicznej. In: W. Kieżun, A. Letkiewicz, J. Wołejsza (eds.). Kooperacje organizacji publicznych (pp. 533-544). Szczytno: Wydawnictwo Wyższej Szkoły Policji w Szczytnie.

Nonaka, I. \& Takeuchi, H. (2000). Kreowanie wiedzy w organizacji. Jak spótki japońskie dynamizuja procesy innowacyjne. Tłum. E. Nalewajko. Warszawa: Poltext. Oleksyn, T. (2006). Zarzqdzanie kompetencjami-teoria i praktyka. Kraków: Oficyna Ekonomiczna.

Penc, J. (2005). Sztuka skutecznego zarzadzania. Kraków: Oficyna Ekonomiczna.

Pocztowski, A. (2003). Zarzqdzanie zasobami ludzkimi. Strategie-procesy-metody. Warszawa: PWE.

Rakowska, A. \& Sitko-Lutek, A. (2000). Doskonalenie kompetencji menedżerskich. Warszawa: PWE. 
Ratajczak, Z. (2007). Psychologia pracy i organizacji. Warszawa: PWN.

Rostowski, T. (2004). Zarządzanie kompetencjami w UE. In: M. Juchnowicz (ed.). Standardy europejskie w zarzadzaniu zasobami ludzkimi (pp. 39-54). Warszawa: Poltext.

Sadler, Ph. (1997). Zarzadzanie w społeczeństwie postindustrialnym. Tłum. M. Bernacki. Kraków: Wydawnictwo Profesjonalnej Szkoły Biznesu.

Sajkiewicz, A. (ed.) (2002). Jakość zasobów pracy. Kultura, kompetencje, konkurencyjność. Warszawa: Poltext.

Słownik jezzyka polskiego. http://sjp.pwn.pl/szukaj/warto\%C5\%9Bci (accessed: $16^{\text {th }}$ March 2017).

Stownik języka polskiego. http://sjp.pwn.pl/szukaj/wiedza (accessed: 19 ${ }^{\text {th }}$ March 2017). Sołocińska, A. (2016). Dzielenie się wiedzą jako istotna kompetencja pracowników. Studia Ekonomiczne. Zeszyty Naukowe Uniwersytetu Ekonomicznego w Katowicach, 258, 86-96.

Stoner, J.A.S. \& Wankel, Ch. (1994). Kierowanie. Tłum. A. Ehrlich. Warszawa: PWE. Turowski, J. (2000). Socjologia. Mate struktury spoteczne. Lublin: Towarzystwo Naukowe Katolickiego Uniwersytetu Lubelskiego.

Walkowiak, R. (2007). Zarzqdzanie zasobami ludzkimi. Kompetencje, nowe trendy, efektywność. Toruń: TNOiK.

Walkowiak, R. (2004). Model kompetencji menedżerów organizacji samorzadowych. Olsztyn: Wydawnictwo Uniwersytetu Warmińsko-Mazurskiego.

Whetten, D., Cameron, K. \& Woods, M. (1996). Developing Management Skills for Europe. Boston: Addison-Wesley.

Whiddett, S. \& Hollyforde, S. (2003). Modele kompetencyjne w zarzadzaniu zasobami ludzkimi. Tłum. G. Sałuda. Kraków: Oficyna Ekonomiczna.

Witaszek, Z. (2011). Rozwój kompetencji menedżerskich przesłanką sukcesu organizacji. Zeszyty Naukowe Akademii Marynarki Wojennej, 4(187), 303-321.

Zhao, X. \& Jia, Z. (2006). Risk Analysis on Human Resource Management, School of Economy and Management. Handan: Hebei University of Engineering.

Zbiegień-Maciąg, L. (ed.) (2006). Nowe tendencje i wyzwania w zarzadzaniu personelem. Kraków: Wolters Kluwer Polska.

Żukowski, P. (2008). Profesjonalna sylwetka współczesnego menedżera. Problemy Profesjologii, 1, 25-40. 


\title{
KOMPETENCJE MENEDŻERÓW W ZAKRESIE ZARZĄDZANIA RYZYKIEM PERSONALNYM
}

\begin{abstract}
Abstrakt
Tło badań. Zarządzanie organizacjami w warunkach turbulentnego otoczenia stawia przed menedżerami wysokie wymagania kompetencyjne. W gospodarce opartej na wiedzy wśród wymaganych na stanowisku kierowniczym kompetencji wzrasta znaczenie umiejętności zarządzania ryzykiem personalnym. Każdy z etapów zarządzania zasobami ludzkimi realizowanego przez menedżerów stanowi bowiem potencjalne źródło ryzyka związanego z koniecznością podejmowania decyzji personalnych. Ryzyko personalne jest wpisane w działalność każdego podmiotu, w którym podsystem społeczny jest elementem niezbędnym i kluczowym dla jego funkcjonowania. Powinno być ono zatem przedmiotem zarządzania, tak jak inne rodzaje ryzyka.
\end{abstract}

Cel badań. Celem podjętych przez autorkę badań była diagnoza kompetencji menedżerów w zakresie zarządzania ryzykiem personalnym.

Metodologia. Artykuł został opracowany na podstawie analizy literatury przedmiotu oraz wyników badań własnych przeprowadzonych metodą sondażu diagnostycznego z wykorzystaniem kwestionariusza ankiety.

Kluczowe wnioski. Na podstawie badań przeprowadzonych metodą sondażu diagnostycznego ustalono, że menedżerowie posiadają znaczny potencjał w zakresie zarządzania tym specyficznym rodzajem ryzyka, który jednak nie we wszystkich organizacjach jest w pełni wykorzystywany. Analizy wykazały ponadto, że bariere ograniczajacca efektywne zarządzanie ryzykiem personalnym ukierunkowane na generowanie wartości dodanej stwarzają negatywne postawy menedżerów, znajdujące wyraz w postrzeganiu ryzyka personalnego przede wszystkim jako zagrożenia i dążeniu do jego unikania.

Słowa kluczowe: kompetencje, ryzyko personalne, zarządzanie ryzykiem personalnym. 